Article

\title{
Materiality in the Seam Space: Sketches for a Transitional Port City Dome District
}

\author{
Stephen J. Ramos \\ College of Environment + Design, University of Georgia, USA; E-Mail: sramos@uga.edu
}

Submitted: 28 January 2021 | Accepted: 30 March 2021 | Published: 27 July 2021

\begin{abstract}
Biomass material volatility generates new opportunities for port-city relationships. Alternative energy markets require specialized port facilities to handle new bulk commodities like biomass. Wood pellets, a type of biomass, present warehousing challenges due to combustion danger. The industrial response to this risk has generated new storage forms for port regions. The return to bulk cargo reintroduces materiality as a focus for port city research, which had generally been regarded as a peripheral concern since the advent of the shipping container. The container had come to represent a borderless, 'fast capitalism' throughput model, but research on port 'accidents' has complicated this reductive globalization narrative. The programmatic dynamism of wood pellet dome structures suggests new spatially-porous possibilities for an interstitial border space at the port-city interface with material commonalities and hybrid potentials for resilient logistics and civic facilities. In contrast to container cargo unitization, the dome signifies the standardization of the coastal/riparian port environment. Dome structures can help ports plan for the complex challenges of cargo material behaviors and increasing extreme weather events. The article begins with wood pellet materiality to then explore programmatic possibilities that industrial construction technology generates. Conceptually, this joins the proposal of port as 'seam space' with port-city resilience planning and the porosity celebrated in recent urbanism literature. Scaling up from wood pellet materiality to an interstitial port-city district, the article contributes to calls for increased attention to materiality as a means to envision new urban agendas.
\end{abstract}

\section{Keywords}

biomass; energy transition; logistics; materiality; port geography; seam spaces

\section{Issue}

This article is part of the issue "Planning for Porosity: Exploring Port City Development through the Lens of Boundaries and Flows" edited by Carola Hein (Delft University of Technology, The Netherlands).

(C) 2021 by the author; licensee Cogitatio (Lisbon, Portugal). This article is licensed under a Creative Commons Attribution 4.0 International License (CC BY).

\section{Introduction}

Wood pellets are a category of biomass, an alternative energy that is part of a larger international strategy for climate change mitigation through carbon reduction (Gumundsdottir et al., 2018, p. 579; Jenkins et al., 2018; Ramos, 2020). Alternative energy markets require specialized port facilities that can handle new bulk commodities like biomass (Dafnomilis, Lodewijks, et al., 2018), which balkanize shipping consolidation around container port facilities. Wood pellet warehousing presents challenges due to dangers of material combustion (Huang \& Rein, 2016), and the industrial response to this risk introduces new storage forms to port regions. The return to bulk cargo raises materiality and its behavior as a focus for port city research, which had heretofore generally been regarded as a peripheral concern with the advent of the shipping container (Gregson et al., 2017). Biomass material volatility-the very potential energy it is transported for-presents challenges that also generate new porous possibilities for port logistics, port-city relationships, and broader port geographies. The issue's theme on port geography and its managed borders is an opportunity to ask how empirical, interdisciplinary study of port functionality and trade flows can inform porous planning practices celebrated in contemporary urbanism literature.

Recent port-city research describes urban waterfront environments as "hybrid (and complex) locations of 
ecological, economic, and social zones of transition and dispersal" (Taufen \& Yocom, 2021, p. 366). Geographer Deborah Cowen (2010) proposes the concept of ports as 'seam spaces' to describe this hybrid condition, within the broader logistics 'space of action' between production and consumption. Increased militarization of urban spaces and global trade routes rely on digital surveillance rather than physical walls for what Urbanist Stephen Graham (2010) terms 'ubiquitous borders'; everywhere yet no where (Cowen, 2014; Khalili, 2020). The port is a node within a broader metropolitan matrix, communicated through overlapping networks of electronic information and transportation, which become more determinant for issues of access and flow than traditional political borders (Wall, 1999, pp. 234-235). Yet in spite of literature that underscores port-city hybridity, transition, and metropolitan infrastructural integration, port-city spatial separation continues to pose planning challenges (Carpenter \& Lozano, 2020; Hein \& van de Laar, 2020; Yu et al., 2020).

In addition to the programmatic and spatial separation of port from city, there are also the ever-increasing risks of sea-level rise and climate change that disproportionately impact port cities. There is now an extensive literature concerning the need for integral planning and design for port and port-city resilience in the face of these risks (Cutter et al., 2008; Cutter et al., 2010; Meyer, 2009; Pelling \& Blackburn, 2013; Ramos, 2021; Rebuild by Design, 2021).

The risk of biomass combustion in warehousing has generated constructed material solutions in domeshaped silos designed to safely store wood pellets in transit. The dome material is also used for shelter spaces to protect communities during extreme weather events. New social opportunities emerge for porous port-city interface when we consider that biomass storage silos can also be programmed as community shelters. An interstitial district with programmatic hybridity could take advantage of building material resilience for improved logistics management against freight 'accidents' (Gregson et al., 2017), while also mitigating the climate risks that port cities increasingly face. Building on materiality and continuous surface research in architecture (Picon, 2020), and that of urban surface programming (Wall, 1999), the article suggests materiality as a renewed field of port city research for logistics and resilience.

The article begins with a selective overview of the literature on porosity and the city, and a review of supply chains, port technology, flows, and borders. After a brief discussion of the port's role in energy transportation, the article then looks at the emergence of biomass as an extractive alternative energy source, and the particular material challenges it poses as it is 'unitized into freight' and transported internationally (Arboleda, 2020; Gregson et al., 2017). After, the article traces the emergence of the dome construction technology and its resilient application in logistics and civic facili- ties. The article then proposes an interstitial district, further integrating port and city, comprised of dome structures for resilient programmatic hybridity in the face of increased material warehousing and extreme weather risks. It is precisely the dome's hermetic protection for each structure-warehouse, school, church, museumfrom internal and external threats that could join those programs, often separated in port cities, to form new porous districts between port and city and better communicate the two. The article's speculative propositionfrom the scale of material behavior to the broad spatial considerations of port-city interface-offers sketches of a more integrative, resilient urban agenda for international port geographies.

\section{Porosity and Ports}

Recent urbanism literature has retrieved Walter Benjamin and Asja Lacis's 1925 essay on the coastal city of Naples as inspiration for 'porous' planning and design (Benjamin, 2005; Sennett, 2015; Stavrides, 2007; Viganò, 2009; Wolfrum et al., 2018). The essay celebrates the material qualities of the city's iconic stone architecture ("porous," "craggy"), and its temporal and open possibilities (Benjamin \& Lacis, 1986). The material becomes a metaphor for how the city's architecture faithfully represents and reproduces its intricate, animated social life. Contemporary authors leverage the porosity metaphor as a variation on the critique of modern planning use/program separation. The metaphor also serves as the basis for the porous city proposal, which encourages social, economic, and use comingling without borders to engender a civic, more vibrant and authentic 21st century city. The "gritty and fleshy realities" of the Naples porous stone (Bakker \& Bridge, 2006, p. 8)-its materiality-are scaled up to imagine such a city, and the inspiration and aspiration for it.

Naples is a port city (De Martino, 2020), and the porosity Benjamin and Lacis celebrate could also describe ports' liminal transition space where sea and land interpenetrate. The port is the 'knot' that joins maritime and land space (Weigend, 1958, p. 185), gazing simultaneously outward to sea and the world beyond and inward toward the hinterland. The port city is a cosmopolitan place where many cultures come together and blend. The pluri- and interdisciplinarity of port research is also testament to its transversal, porous qualities, encompassing a broad spectrum of themes from the technical to the cultural (with many others therein; Hein, 2011; Ng, 2013). The nested scales of research join port, to region, to world, within one another. In 1989, when Manuel Castells wrote of telematic 'spaces of flows' as "the material support of simultaneous social practices communicated at a distance" to describe the new spatial condition of the information age (Castells, 2010 , p. xxxii), in many ways these practices were already centuries old in port cities. 


\section{Seam Space: Borders, Flows, and Accidents}

Port boosters generally advocate for open borders, knowing that more freight handling earns more money. In 1911, E. J. Clapp wrote of the Port of Hamburg, "the port's function is to bring countries into contact, and to enable them with the least possible friction and loss of energy, to effect [exchange between them]" (Herod, 2014 , p. 268). It is the state, of course, which intervenes periodically with policies to regulate borders and trade flows, but the deregulatory initiatives of the 1980s, and the multinational trade bloc agreements of the 1990s helped to promote freer international trade. Accelerated trade coordination helped time conquer space, and the science of logistic management led to a new global 'fast capitalism' (Ohmae, 1989), where just-in-time assembly required increased cargo throughput speeds and greater port efficiency (Golhar \& Stamm, 1991; Klaus \& Muller, 2012). The shipping container also served as metaphor to convey this imaginary of "pure movement of units of information, production, and consumption on the circuits of systems" (Klose, 2015, p. 76; see Gregson et al., 2017).

Much of the early scholarly literature on supply chains comes from sociology and geography. Gereffi and Koreniewicz (1994) developed their foundational model of global commodity chain analysis, and later Gereffi et al. (2001) researched global corporate value chains as the optimal corporate strategy for path efficiency and vertical integration (Bair, 2005; Cattaneo et al., 2010). Critical geography has focused more on issues of ecology and political economy (Bernstein \& Campling, 2006a, 2006b; Hughes \& Reimer, 2004; Sheppard, 2015; Werner, 2020), and the "multiple, simultaneous spatial strategies" (Zalik, 2015, pp. 2452-2453) that capital deploys to construct, balance, and maintain production, distribution, and consumption across supply chains (Simpson, 2019, p. 124; Smith, 1984; Storper \& Walker, 1989). The sites of production and consumption along the supply chain are comprised of "complex interplay of technology, culture, commerce, distribution, their respective and constitutive politics," forming territories that "converge and part dynamically" (Lyster, 2006, p. 221). Tracking these mercurial, shifting geographies helps to reveal the political complexities of supply chain assemblage and border behavior (Ramos, 2020, p. 2).

With the ascendance of the security state after 9/11/01, Geographer Deborah Cowen proposed the concept of ports as 'seam spaces,' transitional zones of authority between inside and outside, opening and closing, where borders are blurred, and porosity policed (Cowen, 2010, p. 603; Gregson et al., 2017). Seam spaces are not merely incidental nodes along a seamless imaginary of global value chain flows conjured in globalization narratives (Ohmae, 2005). Rather, they are zones of security and surveillance that are prone to diverse logistical practices of 'stickiness' and 'frictions' (Gregson, 2017; Herod, 2014; Lawhon, 2013). Seam spaces can be located at national borders or sites for intermodal exchange (each of which are characteristic of ports), but Gregson et al. (2017, p. 383) point out that seam spaces can also occur offsite from ports, in places such as distribution centers, and wholesaler and manufacturing sites where commodities are unpackaged, packaged, and repackaged. The conceptual move helps to identify trade commodity heterogeneity, the value-added function of the logistics chain, and the power of logistics to impact global spatial organization (Cowen, 2014; Tsing, 2009). The observation also helps to consider how traditional onsite port logistics practices and functions are being re-bordered deeper into port hinterlands (Hall \& Jacobs, 2010).

Geographer Michael Simpson (2019, p. 115) offers broad categories for these frictions as either "imperfections, accidents, or disruptions." Imperfections are those points where supply chain design or management has yet to be perfected by logistical sciences (intermodal transfer, cargo heterogenous, unitization), accidents are diverse technological failures along the supply chain, and disruptions occur when human actors try to intentionally disrupt supply chain functionality (Simpson, 2019, pp. 115-117). Simpson (2019, p. 117) recognizes that these categories may vary, depending on where we "draw our line between the internal and the external" of logistics chains. The categorical and conceptual flexibility of that internal/external border distinction gets to the essential challenge of precise articulation of port geography bordering due to the functional, jurisdictional, and spatial complexity of international logistics networks; or, as Simpson (2019, p. 117) poses, "the extent to which we believe that the science of supply chain logistics can effectively manage, govern, or account for the entire vast field of socio-ecological unruliness." Citing contemporary resource geography on materiality and nonhuman objects (Bakker \& Bridge, 2006; Braun, 2005), calls emerged for future research to address the specific material qualities of commodities and how these qualities impact logistics processes, temporalities, and spatial strategies for their movement (Simpson, 2019, p. 125). In the following sections the article addresses this call, and that of the thematic issue, by exploring the materiality of wood pellets in their international transport and storage, and how the risk of combustion accidents can lead to new porous spatial opportunities between port and city.

\section{Energy Transition, Ports, and Biomass}

Ports have long served as essential nodes for energy transportation, particularly since the industrial revolution, for commodities such as coal, petroleum, and natural gas (Hein, 2018; Rodrigue, 2021). More recent recognition of the nefarious impacts of fossil fuel energy on environmental quality, and its central role in global warming, has led to the search for more sustainable energy systems to replace fossil fuels. We are in the midst of an energy transition in which certain countries commit 
gradually to alternative energy sources with the intention, however far off in the future, toward full independence from fossil fuel use (Hafner \& Tagliapietra, 2020). One such alternative energy source is biomass. Examples of biomass include cordwood, waste paper, wood chips, wood pellets, and select agricultural products and byproducts considered to be renewable energy sources (Pellet Fuel Institute, 2019).

The 1997 United Nations Framework Convention on Climate Change (UNFCCC) Kyoto Protocol determined that in order to transition toward a more sustainable energy system, biomass energy would be categorized as carbon neutral, and was eligible for alternative energy credits and incentives (UNFCCC, 2008). There is scientific debate as to whether biomass is, in fact, carbon neutral, or heavily carbon positive, depending on how much of the overall biomass supply chain cycle one chooses to quantify and over what length of time (Canham, 2013; Johnson, 2009). Nevertheless, both the European Union (EU) and United Kingdom authorities have repeatedly backed the carbon-neutral categorization for biomass energy, and EU member countries are committed to it in their strategic goals for energy transition (Brack et al., 2018; European Climate Foundation, 2019; European Commission on Energy, 2019; Volpi, 2019). Japan's Feed-In Tariff program commits to have biomass comprise $20 \%$ of its renewable energy generation-approximately 15 and 20 million tons per year (MTPY)-by 2030 both for domestic residential use and for major utility companies (Forest2Market, 2019, p. 11). South Korean wood pellet demand could be over eight MTPY by 2025. These new markets, along with others, will search all parts of the globe for lumber feedstock to sustain this alternative energy generation (Fischer et al., 2019; Mai-Moulin et al., 2019; Proskurina, 2018). Similar to other energy sources, the biomass industry engages in "aggressive pursuit of economies of scale in production and refining, and in transportation" (Bridge, 2008, p. 406; see Watts, 2009), with the addition political incentives of climate change and low-carbon energy transition credits.

In transit, biomass is considered a bulk material, in the category of minerals, earthly materials, processed materials, and agricultural products (Shah, 2017, p. 3). But biomass requires specialized port equipment during its transport and storage due to its material volatility (Dafnomilis, Lodewijks, et al., 2018, p. 148; Hancock et al., 2016), and specialized ocean vessels to transport it (Svedberg et al., 2008). Biomass decomposition in transit produce safety risks of dust production and explosion, self-heating and ignition, and respiratory issues (Craven et al., 2015). Specialized port equipment includes 'grabs' to minimize product deterioration, enclosed transportation and storage facilities, spark detectors, fire detection, and temperature monitoring (Dafnomilis, Duinkerken, et al., 2018; Dafnomilis, Lodewijks, et al., 2018). Some of these safety issues have been partially mitigated through industry ware- house material research and development, but the dangers still exist (Kittler et al., 2020). Wood materiality is essential to the technology and infrastructure of the biomass supply chain network (Bakker \& Bridge, 2006; Braun, 2005; Simpson, 2019, p. 125). Biomass objects are contingent, volatile, almost ephemeral, but their materiality is the core of their state sustainability claims mentioned above (Harris, 2017; Nightingale, 2018; Ramos, 2020). The following section explores the materiality of biomass wood pellets.

\section{Wood Pellet Materiality}

Wood pellets are unitized potential energy units formed through a denaturing process that packages saw dust in casings to endure one migratory trip through the supply chain (Figure 1). To make the pellets, a raw material is developed from multiple sources of wood, which is dried and extruded using special dies. After, the material is exposed to high pressure $(45,000 \mathrm{PSI})$ and temperatures $\left(110-130^{\circ} \mathrm{C}\right)$, and the wood's lignin softens and coheres to form the pellets (Jones \& Harper, 2009). Wood pellets are low in moisture content: $4-8 \%$ water content, compared with $26 \%$ water of raw biomass (Jones \& Harper, 2009). They are also low in ash content (1-3\%, due to very low bark content), which produces a higher British thermal unit energy value (Ramos, 2020, p. 5). Their uniform size-designated in the International Organization for Standardization ISO 7225-2-allows for standardized storage, processing, and transportation, which helps save costs (Ramos, 2020, p. 5; Thrän et al., 2019).

In spite of wood pellet promise as an alternative energy, its global transport and storage have been plagued continually by smoldering fires (Biofuel Watch, 2021; Dust Safety Science, 2020; Hobbs, 2019). Some of these fires occur at pellet plants, but most occur at warehouse facilities on or near port grounds. Pellets are stored in large bulk piles, where they occasionally produce spontaneous combustion 'hot spots' throughout the piles that cause extended smoldering fires. The fires are difficult to extinguish because they can be located deep within the pile (Huang \& Rein, 2016). Older pellet warehouses made of wood with asphalt roofs have been consumed in smoldering fires, as have newer aluminum and steel warehouses with state-of-the-art sprinkler systems (Hobbs, 2019).

Recalling Simpson's categories of port frictions, pellet fires are both imperfections and accidents. The logistics managerial science has yet to resolve the system design to avoid pellet combustion, and the safety systems (sprinkler systems, etc.) either fail, or are not sufficiently able to protect the warehouse structure. Also recalling Simpson's point about where to define the border between inside and outside the process, warehouse construction companies suggest the fires are sometimes caused by combustion that occurs outside the warehouse and have accidently been brought in by conveyor belt (personal communication with Lane 

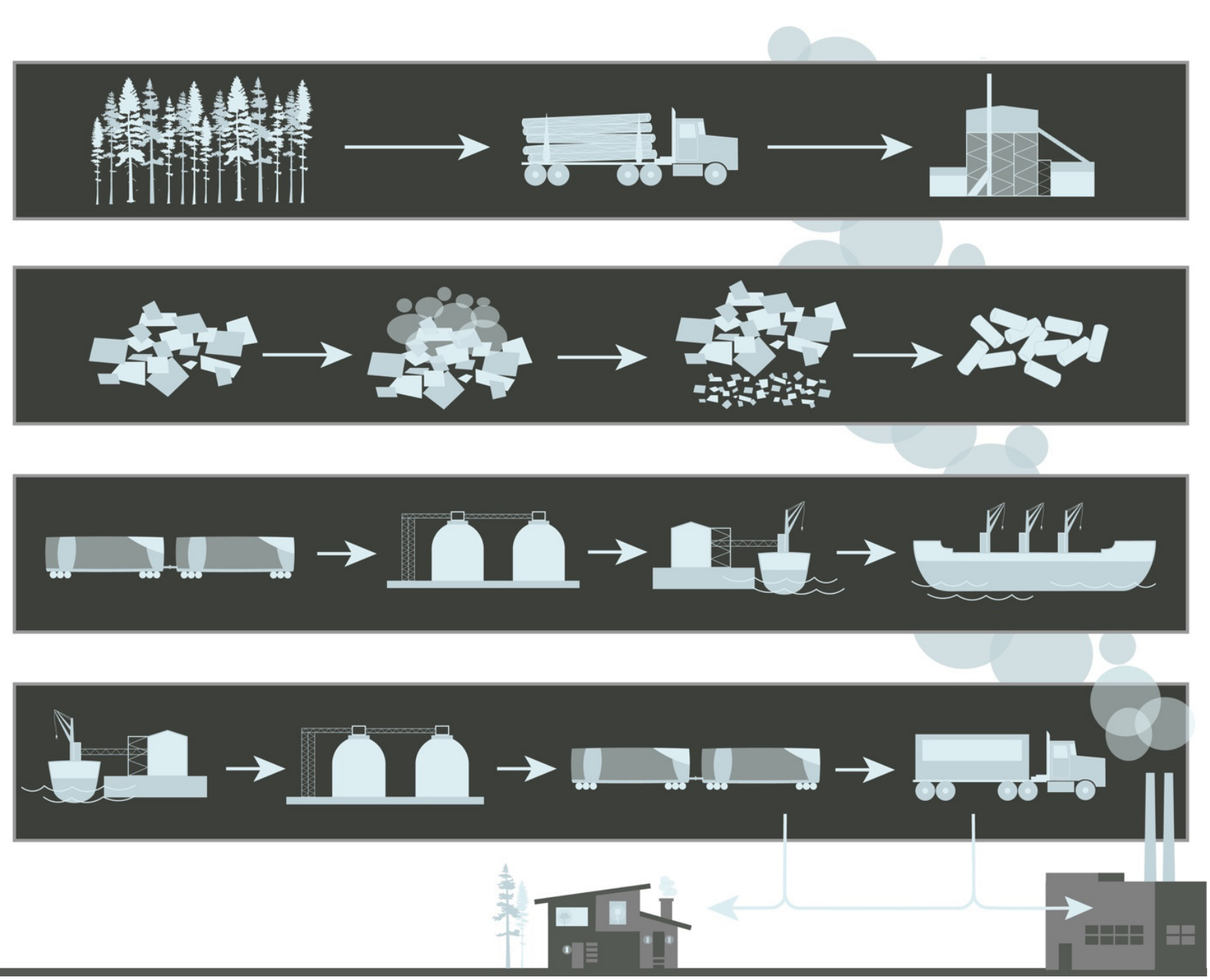

Figure 1. Wood pellet supply chain diagram. Source: Ramos (2020, p. 6).

Roberts, November 23, 2020). A company in the United States northwest with a history of grain storage facilities designed new warehouses that reduce dust accumulation with vibrating floors, gravity-fed loading, and limited oxygen silos to mitigate wood pellet combustion risk.

\section{Dome and Dome District}

The Dome Technology company began in Idaho in the late 1970s. They developed a patent for dome construction that begins by inflating a form, attaching an insulated layer of urethane, applying a reinforced steel mesh, and then applying a cementitious material. Once the structure is sufficiently dry and supported, the original inflated elements is removed (South \& South, 1979; Figure 2). The dome structures were used for diverse bulk storage, including grain, fertilizer, cement, sugar, and coal (Dome Technology, 2021).

In 2010, the Peeples Industries in Savannah, Georgia needed to expand their wood pellet storage capacity due to their increasing success in shipping wood pellets to European markets in the United Kingdom, Belgium, and the Netherlands (Ramos, 2020). They contacted Dome
Technologies, and after seeing that they could save money with increased material risk mitigation, Peeples contracted two wood pellet storage domes, each with a diameter of $200-\mathrm{ft}$ and $100-\mathrm{ft}$ height and a capacity of 25,000t (Dome Technology, 2021; Figures 3 and 4). Dome Technology partnered with Drax and Enviva, two of the world's largest wood pellet producers, and their domes are now the industry standard for wood pellet warehousing (Figure 5).

In addition to warehousing, the company's domes have also been used for community storm shelters, beginning with their first project in 2004 in Beggs, Oklahoma. The dome construction technology meets the Federal Emergency Management Agency 361, ICC-500, and National Storm Shelter Association standards for protection against tornadoes, hurricanes, and typhoons. The construction material is approved to withstand hurricane and tornado winds exceeding $250 \mathrm{mph}$ (Dome Technology, 2021). The shelters are located on school campuses, and when not serving as protection shelters they are used as gymnasiums (Figure 6). The domes are also used for faith centers and museums (Dome Technology, 2021; Figure 7). 


\section{COGITATIO}

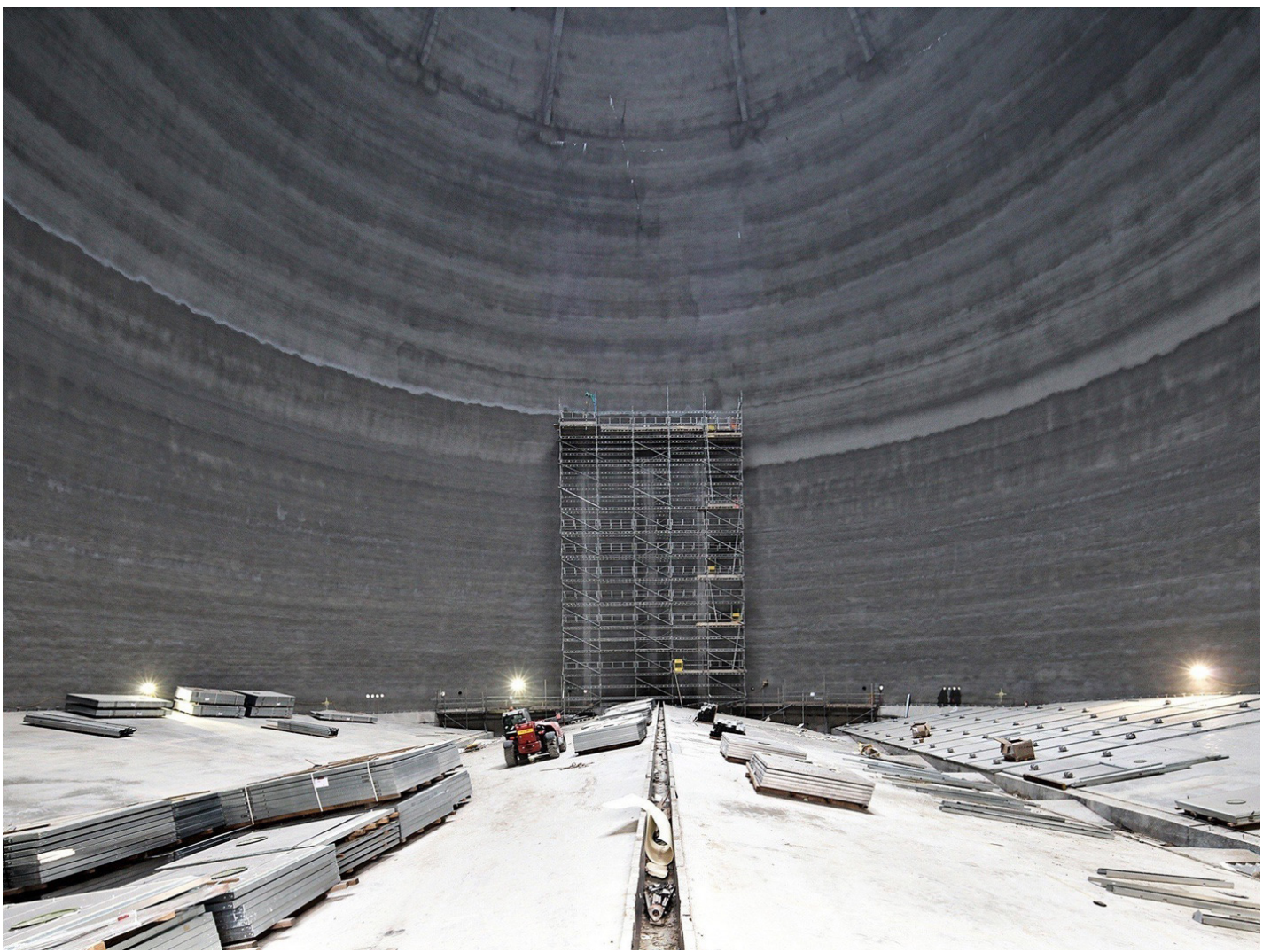

Figure 2. Dome silos under construction at the 20 Power Station in Selby, North Yorkshire, England. Source: Dome Technology (2021).

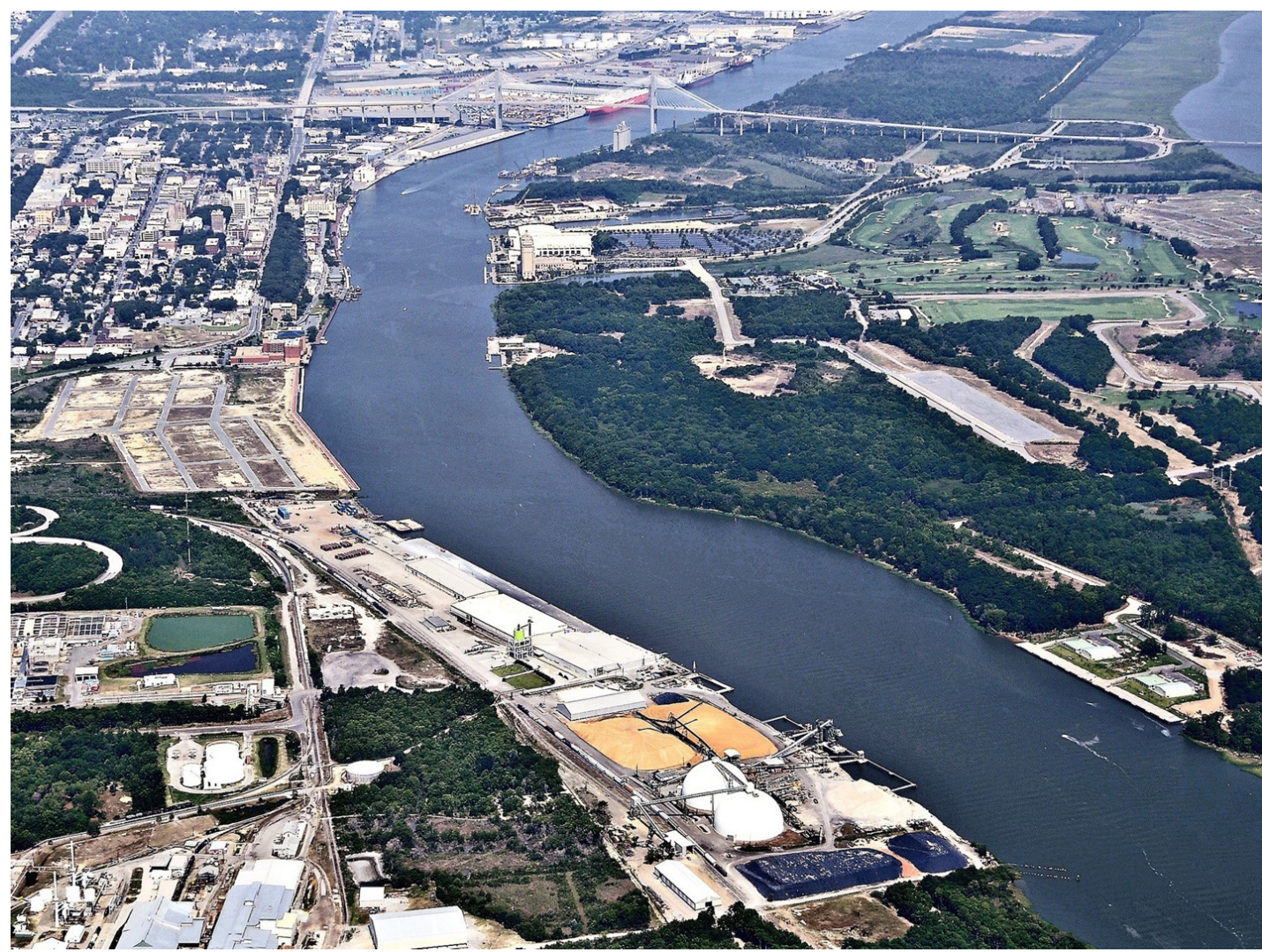

Figure 3. Peeples Industries-Wood Pellet bulk storage at the East Coast Terminal on the Savannah River. Source: Dome Technology (2021). 


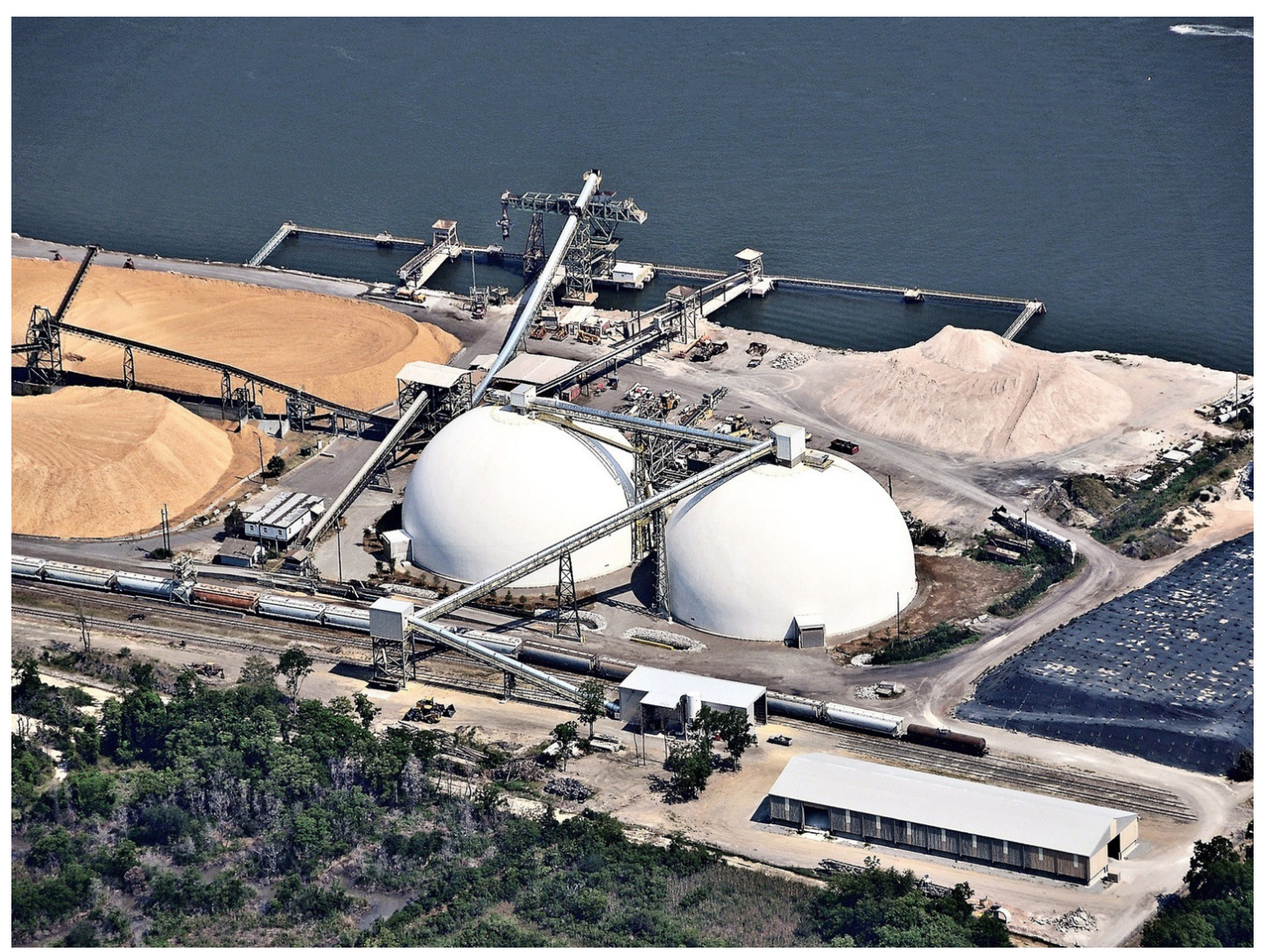

Figure 4. Peeples Industries-Wood Pellet bulk storage silos. Source: Dome Technology (2021).

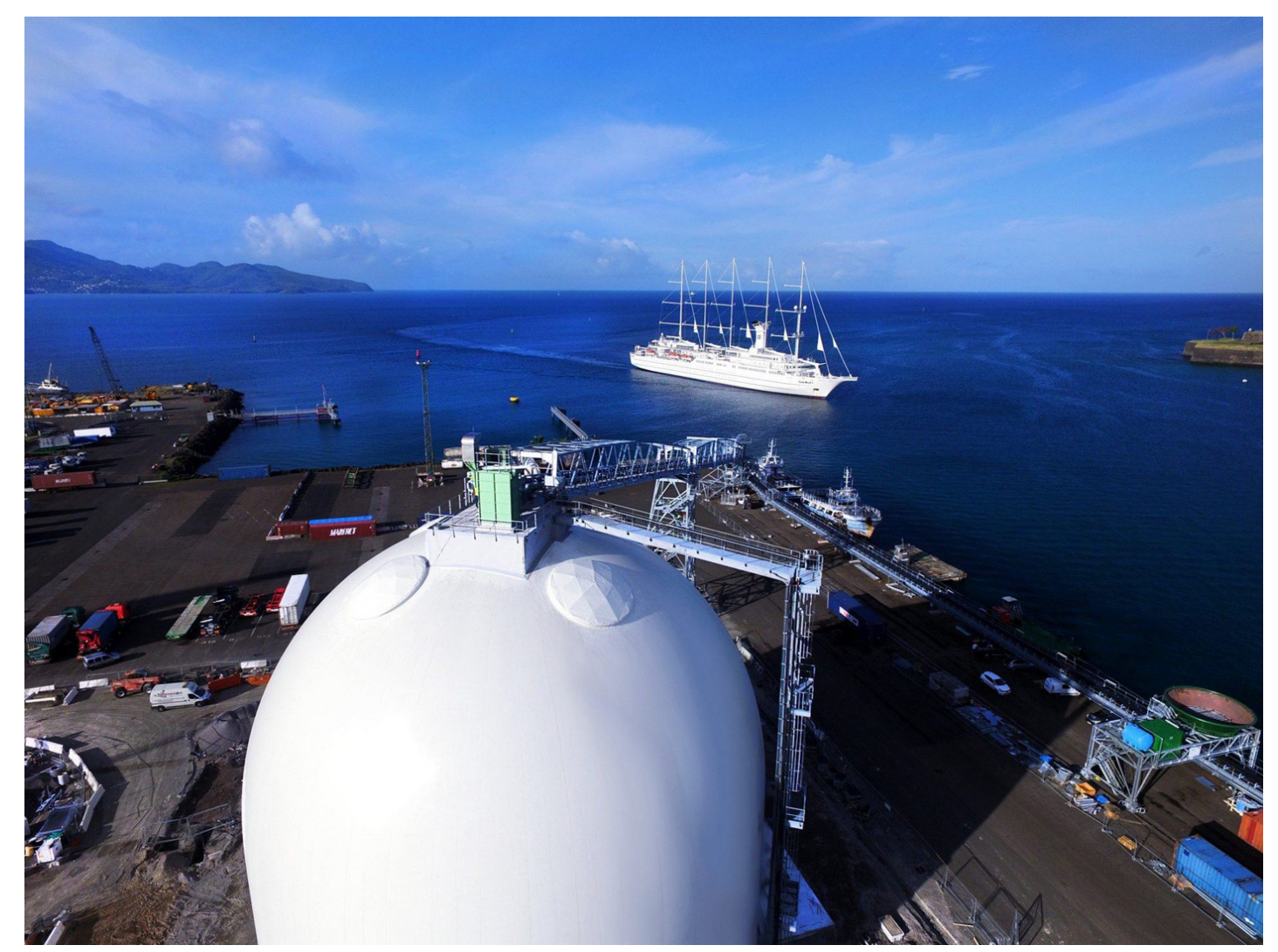

Figure 5. Albioma Wood Pellet Dome in Martinique. Source: Dome Technology (2021). 


\section{COGITATIO}

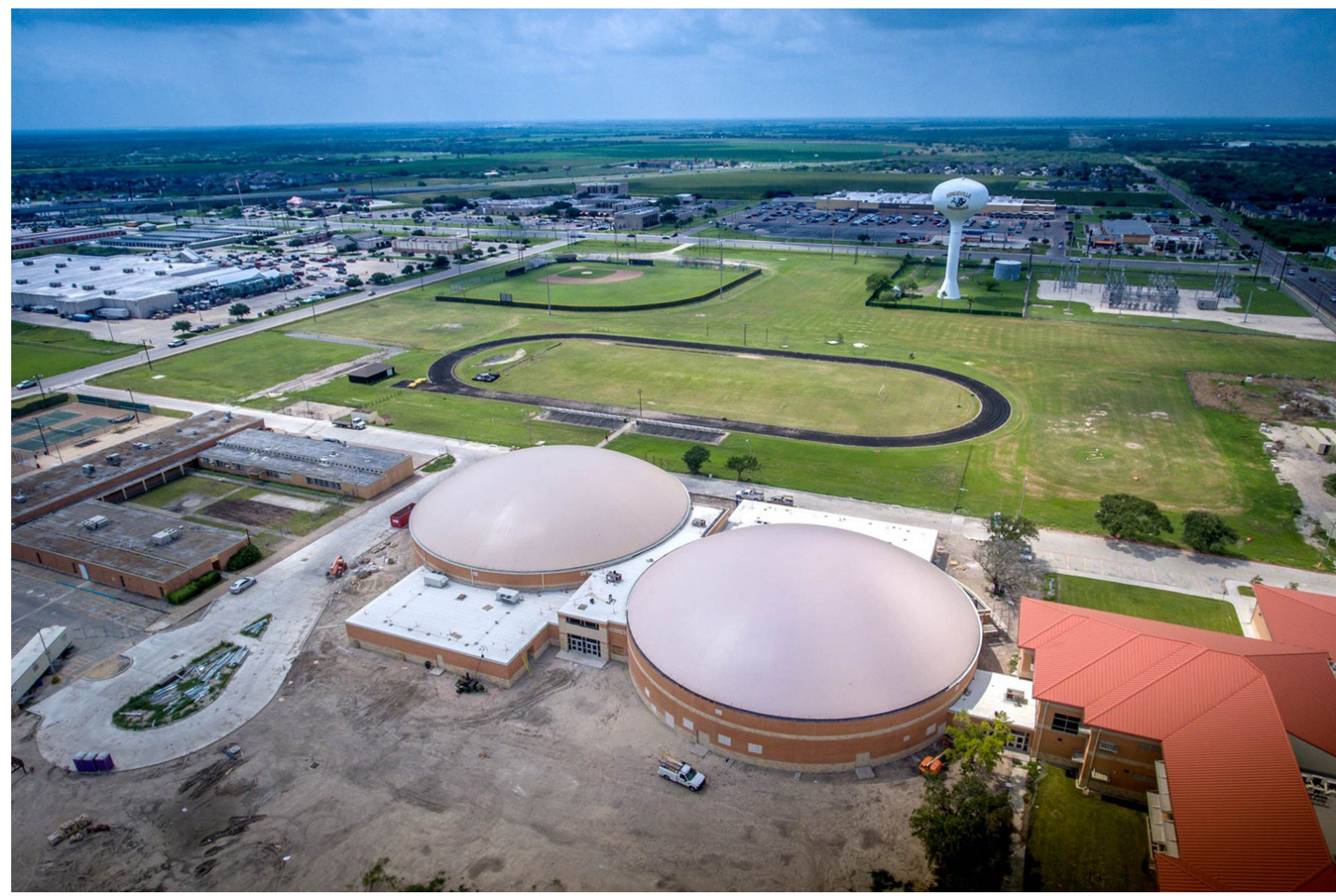

Figure 6. Kingsville Independent School District Community storm shelter in Kingsville, Texas, on the Gulf Coast. Source: Dome Technology (2021).

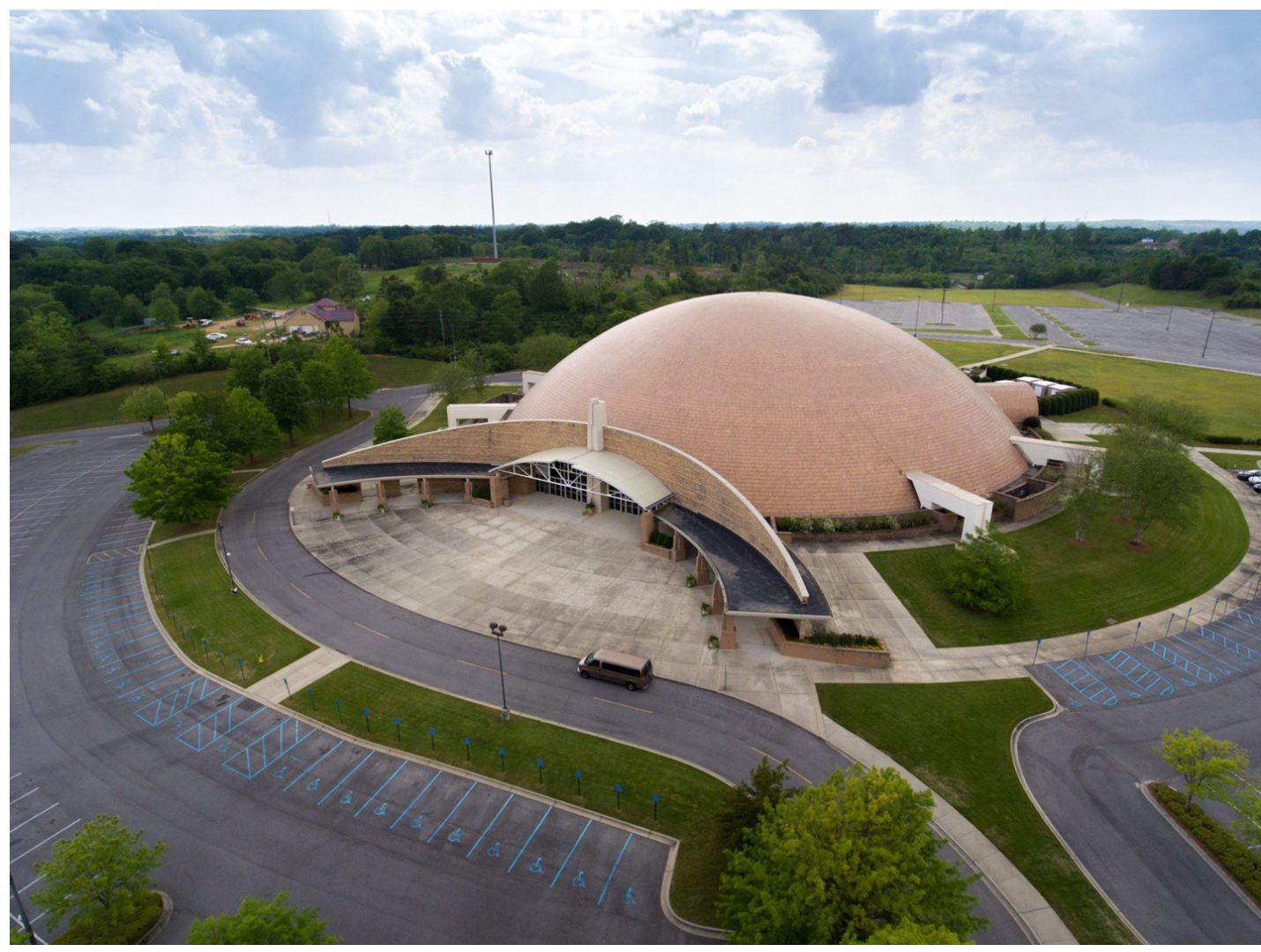

Figure 7. 73-ft high dome at Faith Chapel in Birmingham, Alabama, completed in December 2002. Source: Dome Technology (2021). 
The dome construction provides safety through isolation, the essence of modernist separation. But this material commonality in which the dome helps to protect human and non-human cargo from internal and external environmental threats is an opportunity to scale up. Material commonality might help to design dome districts as liminal, transitional spaces that could enable more porous communication between ports and cities.

One can begin to imagine the dome district: Shelter domes in the district could be used as gymnasiums, churches, and museums when there is no weather threat. Each structure could also have space reserved for pellet warehousing for unexpected spikes in import or export that overwhelm storage capacity, as has often been the case during the excess and scarcity that ports have faced during the Covid-19 pandemic. Seasonality (hurricane seasons, production schedules, consumer heating needs, etc.), temporality (rise and fall of warehouse activity depending on time of the day), and culture (kinds of sports, worship, leisure activities particular to each port city culture) are just some of the many factors to consider for flexible, responsive dome programming. Dome housing could also be included for port and dome district workers. The housing would be useful in the case of longer, more extreme weather events, when it could offer additional comfort and privacy possibilities to the mass gymnasium shelters.

These are very brief sketches, but it is not difficult to see how such a district could integrate warehousing and civic facilities in a transition space between port and city, and perhaps more importantly, serve as central, easily identifiable resilient gathering and protection locations for port cities.

\section{Port Material Futures}

"Let us listen to the counsels of American engineers. But let us beware of American architects!" (Le Corbusier, 1986, p. 42; see Banham, 1986). Le Corbusier, along with other modern architects, took formal inspiration from the industrial grain elevators and silos located along the United States railroad corridors from the nineteenth century. In this light, we can find new formal and programmatic potential for the dome as part of a new logistics cluster for the port's intermodal seam space. If the shipping container revolutionized the wave of cargo freight standardization (Cudahy, 2006; Levinson, 2006), the dome, at once, standardizes the coastal/riparian port environment, and, in its material resilience and formal plasticity, enables new programmatic diversity at multiple sites and scales. The metaphor is not as poetic or immediate as the craggy Neapolitan stone, but the dome material and the protective seal it provides suggest adaptive possibilities that could increase porosity between industrial port spaces and public civic spaces-a new 'knot' (Weigend, 1958, p. 185). The dome material itself is hermetic, impermeable, but its programmatic adaptability may provide new communication and integration of port and city functions that have frequently been identified as planning challenges for port cities (Carpenter \& Lozano, 2020).

These material and contextual commonalities are what Geographer Cindi Katz (2001, p. 1230) refers to as the 'contour lines' across global supply chains, which help to analyze larger themes without losing site of situated knowledges and experiences (Fischer et al., 2019, p. 179; Haraway, 1988). The dome is a risk form for the 21st century port (Beck, 1992; Schubert, 2019).

\section{Conclusion}

Inspired by the material celebration of porous stone as metaphor in Benjamin and Lacis's essay (1986), the article considers flows and borders in energy transition and biomass global logistics, and the particular material behavior of wood pellets in warehousing and transit. Cowen's (2010) proposal of ports as seam spaces and Simpson's (2019) proposal of logistics imperfections and accidents help provide a new frame for port protagonism in global supply chains (see also Hall \& Jacobs, 2010). Wood pellet volatility, and the risk of its combustion have precipitated innovation in constructed material and safety system solutions through dome technology; a construction technique which, until 2010, was used for other kinds of bulk storage. The dome construction technology has diversified and is also used for civic spaces such community shelters and faith centers. The dome construction resilience helps to envision how it might be deployed in the design of dome districts, within port seam spaces, that could include programs of bulk warehousing, community shelters for extreme weather events, and even more quotidian uses such as museums and gymnasiums. Further, the material would also facilitate programmatic diversity within individual dome structures that could potential fuse industrial and civic functions. Given the multiple challenges that port cities face in planning for security, resilience, economic trade flow pressures (Mansouri et al., 2010), and calls for increased porous communication between port and city at various scales, these dome sketches help to envision how the design of such porous districts could begin to address these multiple challenges. Challenges which, moving forward, will only increase in scale and complexity.

\section{Conflict of Interests}

The author declares no conflict of interests.

\section{References}

Arboleda, M. (2020). Planetary mine: Territories of extraction under late capitalism. Verso.

Bair, J. (2005). Global capitalism and commodity chains: Looking back, going forward. Competition and Change, 9(2), 153-180.

Bakker, K., \& Bridge, G. (2006). Material worlds? 
Resource geographies and the 'matter of nature.' Progress in Human Geography, 30(1), 5-27.

Banham, R. (1986). A concrete Atlantis: U.S. industrial building and European modern architecture. MIT Press.

Beck, U. (1992). Risk society: Towards a new modernity (M. Ritter, Trans.). Sage Publications. (Original work published 1986)

Benjamin, A. (2005). Porosity at the edge: Working through Benjamin's "Naples." Architectural Theory Review, 10(1), 33-43.

Benjamin, W., \& Lacis, A. (1986). Naples. In P. Demetz (Ed.), Reflections: Essays, aphorisms, autobiographical writings (pp. 163-173). Schocken.

Bernstein, H., \& Campling, L. (2006a). Commodity studies and commodity fetishism I: Trading down. Journal of Agrarian Change, 6(2), 239-264.

Bernstein, H., \& Campling, L. (2006b). Commodity studies and commodity fetishism II: Profits with principles? Journal of Agrarian Change, 6(3), 414-447.

Biofuel Watch. (2021). Playing with fire: Wood pellets, fires and explosions. https://www.biofuelwatch.org. uk/2014/wood-pellet-accidents

Brack, D., Hewitt, J., \& Marchand, T. M. (2018). Woody biomass for power and heat: Demand and supply in selected EU member states (Chatham House Research Paper). The Royal Institute of International Affairs.

Braun, B. (2005). Environmental issues: Writing a morethan-human urban geography. Progress in Human Geography, 29(5), 635-650.

Bridge, G. (2008). Global production networks and the extractive sector: Governing resource-based development. Journal of Economic Geography, 8(3), 389-419.

Canham, C. D. (2013). Carbon cycle implications of forest biomass energy production in the Northeastern United States. In M. Jacobson \& D. Ciolkosz (Eds.), Wood-based energy in the Northern forests (pp. 61-78). Springer.

Carpenter, A., \& Lozano, R. (2020). European port cities in transition: Moving towards more sustainable sea transport hubs. Springer.

Castells, M. (2010). The information age: Economy, society and culture. Volume 1: The rise of the network society (2nd ed.). Wiley-Blackwell.

Cattaneo, O., Gereffi, G., \& Staritz, C. (2010). Global value chains in a post-crisis world: A development perspective. World Bank Group.

Clapp, E. J. (1911). The port of Hamburg. Yale University Press.

Cowen, D. (2010). A geography of logistics: Market authority and the security of supply chains. Annals of the Association of American Geographer, 100(3), 600-620.

Cowen, D. (2014). The deadly life of logistics: Mapping violence in global trade. University of Minnesota Press.
Craven, J. M., Swithenbank, J., Sharifi, V. N., PeraltaSolorio, D., Kelsall, G., \& Sage, P. (2015). Hydrophobic coatings for moisture stable wood pellets. Biomass and Biodiversity, 80, 278-285.

Cudahy, B. (2006). Box boats: How container ships changed the world. Fordham University Press.

Cutter, S. L., Barnes, L., \& Emrich, C. (2010). Disaster resilience indicators for benchmarking baseline conditions. Journal of Homeland Security and Emergency Management, 7(1), Article 51.

Cutter, S. L., Barnes, L., Berry, M., Burton, C., Evans, E., Tate, E., \& Webb, J. (2008). A place-based model for understanding community resilience to natural disaster. Global Environmental Change, 18, 598-606.

Dafnomilis, I., Duinkerken, M. B., Junginger, M., Lodewijks, G., \& Schott, D. L. (2018). Optimal equipment deployment for biomass terminal operations. Transportation Research Part E, 115, 147-163.

Dafnomilis, I., Lodewijks, G., Junginger, M., \& Schott, D. L. (2018). Evaluation of wood pellet handling in import terminals. Biomass and Bioenergy, 117, 10-23.

De Martino, P. (2020). Defending the past by challenging the future: Spatial and institutional path dependencies in the Naples port-city region. Regional Studies, Regional Science, 7(1), 108-117.

Dome Technology. (2021). Homepage. https://www. dometechnology.com

Dust Safety Science. (2020, January 13). Smouldering fire ignites in silo containing 10,000 tons of wood pellets. https://dustsafetyscience.com/pellet-fire-portarthur-texas

European Climate Foundation. (2019). European roadmap 2050. Roadmap 2050. https://www. roadmap2050.eu

European Commission on Energy. (2019). Renewable energy directive sustainability criteria. European Commission. https://ec.europa.eu/energy/en/ topics/renewable-energy/biofuels/sustainabilitycriteria

Fischer, K., Giertta, F., \& Hajdu, F. (2019). Carbonbinding biomass or a diversity of useful trees? (Counter)topographies of carbon forestry in Uganda. Environment and Planning E: Nature and Space, 2(1), 178-199.

Forest2Market. (2019). Demand for biomass pellets and chips: Japan and South Korea. Forest2Market. https://cdn2.hubspot.net/hubfs/299583/2016_ Website/Documents/Asian\%20Campaign/Demand \%20for\%20Biomass\%20Pellets\%20Chips\%20from \%20Biopower\%20Producers\%20in\%20Japan\%20 South\%20Korea.pdf

Gereffi, G., \& Koreniewicz, M. (1994). Commodity chains and global capitalism. Praeger.

Gereffi, G., Humphrey, J., Kaplinsky, R., \& Sturgeon, T. (2001). Globalisation, value chains, and development. IDS Bulletin, 32(1).

Golhar, D. Y., \& Stamm, C. L. (1991). The just-in-time philosophy: A literature review. International Journal of 
Production Research, 29(4), 657-676.

Graham, S. (2010). Cities under siege: The new military urbanism. Verso.

Gregson, N. (2017). Logistics at work: Trucks, containers and the friction of circulation in the UK. Mobilities, 12(3), 343-364.

Gregson, N., Crang, M., \& Antonopoulos, C. N. (2017). Holding together logistical worlds: Friction, seams and circulation in the emerging 'global warehouse.' Environment and Planning D: Society and Space, 35(3), 381-398.

Gumundsdottir, H., Carton, W., Busch, H., \& Rmasar, V. (2018). Modernist dreams and green sagas: The neoliberal politics of Iceland's renewable energy economy. Environment and Planning E: Nature and Space, 1(4), 579-601.

Hafner, M., \& Tagliapietra, S. (2020). The global energy transition: A review of the existing literature. In $\mathrm{M}$. Hafner \& S. Tagliapietra (Eds.), The geopolitics of the global energy transition (pp. 1-24). Springer.

Hall, P. V., \& Jacobs, W. (2010). Shifting proximities: The maritime ports sector in an era of global supply chains. Regional Studies, 44(9), 1103-1115.

Hancock, V. E., Dafnomilis, I., Schott, D. L., \& Lodewijks, G. (2016). Torrefied biomass and its handling aspects: A state-of-the-art review. Delft University of Technology. http://resolver.tudelft.nl/uuid:7763a29e-976544f3-a5da-5bfd6e5df750

Haraway, D. (1988). Situated knowledges: The science question in feminism and the privilege of partial perspective. Feminist Studies, 14(3), 575-599.

Harris, L. M. (2017). Political ecologies of the state: Recent interventions and questions going forward. Political Geography, 58, 90-92.

Hein, C., \& van de Laar, P. (2020). The separation of ports from cities: The case of Rotterdam. In A. Carpenter \& R. Lozano (Eds.), European port cities in transition: Moving towards more sustainable sea transport hubs (pp. 265-286). Springer.

Hein, C. (2011). Port cities: Dynamic landscapes and global networks. Routledge.

Hein, C. (2018). Oil spaces: The global Petroleumscape in the Rotterdam/The Hague area. Journal of Urban History, 44(5), 887-929.

Herod, A. (2014). Ports as places of stickiness in a world of global flows. In A. R. Ross (Ed.), Grabbing back: Essays against the global land grab (pp. 267-280). AK Press.

Hobbs, L. (2019, April 21). Fire erupts again among the wood pellets at Logistec. The Brunswick News.

Huang, X., \& Rein, G. (2016). Thermochemical conversion of biomass in smouldering combustion across scales: The roles of heterogeneous kinetics, oxygen and transport phenomena. Bioresource Technology, 207, 409-421.

Hughes, A., \& Reimer, S. (2004). Geographies of commodity chains. Routledge.

Jenkins, J. D., Luke, M., \& Thernstrom, S. (2018). Getting to zero carbon emissions in the electric power sector. Joule, 2(12), 2498-2510.

Johnson, E. (2009). Goodbye to carbon neutral: Getting biomass footprint right. Environmental Impact Assessment Review, 29(3), 165-168.

Jones, D., \& Harper, D. (2009). Wood pellets: An introduction to their production and use. The University of Tennessee Institute of Agriculture.

Katz, C. (2001). On the grounds of globalization: A topography for feminist political engagement. Signs: Journal of Women in Culture and Society, 26, 1213-1234.

Khalili, L. (2020). Sinews of war and trade: Shipping and capitalism in the Arabian Peninsula. Verso.

Kittler, B., Stupak, I., \& Tattersall-Smith, C. (2020). Assessing the wood sourcing practices of the U.S. industrial wood pellet industry supplying European energy demand. Energy, Sustainability and Society, 10, Article 23.

Klaus, P., \& Muller, S. (2012). The roots of logistics: A reader of classical contributions to the history and conceptual foundations of the science of logistics. Springer.

Klose, A. (2015). The container principle: How a box changes the way we think (C. Marcrum, Trans.). MIT Press. (Original work published 2009)

Lawhon, M. (2013). Flows, friction and the sociomaterial metabolization of alcohol. Antipode, 45(3), 681-701.

Le Corbusier. (1986). Towards a new architecture (13th French edition; F. Etchells, Trans.). Dover Publications, Inc. (Original work published 1923)

Levinson, M. (2006). The box: How the shipping container made the world smaller and the world economy bigger. Princeton University Press.

Lyster, C. (2006). Landscapes of exchange: Re-articulating site. In C. Waldheim (Ed.), The landscape urbanism reader (pp. 219-237). Princeton Architecture Press.

Mai-Moulin, T., Visser, L., Fingerman, K. R., Elbersen, W., Elbersen, B., Nabuurs, G.-J., Fritsche, U. R., Colmenar, I. D. C., Rutz, D., Diaz-Chavez, R. A., Roozen, A., Weck, M., Iriarte, L., Pelkmans, L., Gonzalez, D. S., Janssen, R., \& Junginger, M. (2019). Sourcing overseas biomass for EU ambitions: Assessing net sustainable export potential from various sourcing countries. Biofuels, Bioproducts \& Biorefining, 13(2), 293-324.

Mansouri, M., Nilchiani, R., \& Mostashari, A. (2010). A policy framework for resilient port infrastructure systems. Marine Policy, 34(6), 1124-1134.

Meyer, H. (2009). Reinventing the Dutch Delta: Complexity and conflicts. Built Environment, 35(4), 432-451.

$\mathrm{Ng}$, A. K. Y. (2013). The evolution and research trends of port geography. The Professional Geographer, 65(1), 65-86.

Nightingale, A. J. (2018). The socioenvironmental state: Political authority, subjects, and transformative socionatural change in an uncertain world. Environment and Planning E: Nature and Space, 1(4), 688-711.

Ohmae, K. (1989). Managing in a borderless world. Har- 
vard Business Review, 1989(May), 2-9.

Ohmae, K. (2005). The next global stage: Challenges and opportunities in our borderless world. Wharton School Publishing.

Pellet Fuel Institute. (2019). What are pellets? https:// www.pelletheat.org/what-are-pellets-

Pelling, M., \& Blackburn, S. (2013). Megacities and the coast: Risk, resilience, and transformation. Routledge.

Picon, A. (2020). The materiality of architecture. University of Minnesota Press.

Proskurina, S. (2018). International trade in biomass for energy production: The local and global context [Doctoral dissertation, Lappeenranta University of Technology].

Ramos, S. J. (2020). Biomass logistics: Mythistory and sociotechnical imaginary in Trans-Atlantic wood pellet assemblage. Environment and Planning E: Nature and Space. Advance online publication. https://doi. org/10.1177/2514848620979311

Ramos, S. J. (2021). Resilience, path dependence, and the port: The case of Savannah. Journal of Planning History, 47(2), 250-271.

Rebuild by Design. (2021). Homepage. http://www. rebuildbydesign.org

Rodrigue, J. P. (2021). 8.3: Ports and energy. In T. Notteboom, A. Pallis, \& J. P. Rodrigue (Eds.), Port economics, management and policy. Routledge. Advance online publication. https://porteconomics management.org/pemp/contents/part8/ports-andenergy

Schubert, D. (2019). Cities and plans: The past defines the future. Planning Perspectives, 34(1), 3-23.

Sennett, R. (2015, November 27). The world wants more 'porous' cities: So why don't we build them? The Guardian. https://www.theguardian.com/cities/ 2015/nov/27/delhi-electronic-market-urbanistdream

Shah, K. P. (2017). Fundamentals, troubleshooting \& maintenance of ash handling plants and pneumatic conveying systems for bulk materials. Practical Maintenance. https://practicalmaintenance.net/wpcontent/uploads/Maintenance-of-Ash-HandlingPlants-and-Pneumatic-Conveying-Systems.pdf

Sheppard, E. (2015). Thinking geographically: Globalizing capitalism and beyond. Annals of the Association of American Geographers, 105(6), 1113-1134.

Simpson, M. (2019). The annihilation of time by space: Pluri-temporal strategies of capitalist circulation. Environment and Planning E: Nature and Space, 2(1), 110-128.

Smith, N. (1984). Uneven development: Nature, capital, and the production of space. Blackwell.

South, D. B., \& South, B. (1979). U.S. Patent 4,155,967 (May 22, 1979).

Stavrides, S. (2007). Heterotopias and the experience of porous urban space. In K. A. Franck \& Q. Stevens (Eds.), Loose space: Possibility and diversity in urban life (pp. 174-193). Routledge.

Storper, M., \& Walker, R. (1989). The capitalist imperative: Territory, technology, and industrial growth. Blackwell.

Svedberg, U., Samuelsson, J., \& Melin, S. (2008). Hazardous off-gassing of carbon monoxide and oxygen depletion during ocean transportation of wood pellets. Annals of Occupational Hygiene, 52(4), 259-266.

Taufen, A., \& Yocom, K. (2021). Transitions in urban waterfronts: Imagining, contesting, and sustaining the aquatic/terrestrial interface. Sustainability, 13, 366.

Thrän, D., Schaubach, K., Peetz, D., Junginger, M., Mai-Moulin, T., Schipfer, F., Olssson, O., \& Lamers, P. (2019). The dynamics of the global wood pellet markets and trade: Key regions, developments and impact factors. Biofuels, Bioproducts \& Biorefining, 13, 267-280.

Tsing, A. (2009). Supply chains and the human condition. Rethinking Marxism: A Journal of Economics, Culture \& Society, 21(2), 148-176.

United Nations Framework Convention on Climate Change. (2008). What is the Kyoto Protocol?

Viganò, P. (2009). The metropolis of the twenty-first century: The project of a porous city. OASE, 2009(80), 91-107.

Volpi, G. (2019, May 2). RED II: EU sustainability criteria for bioenergy [Paper presentation]. University of Georgia Warnell School of Forestry and Natural Resources Adequacy of Spatial databases for Conducting Risk Assessment International Workshop, Athens, GA, USA.

Wall, A. (1999). Programming the urban surface. In J. Corner (Ed.), Recovering landscape: Essays in contemporary landscape architecture (pp. 232-249). Princeton Architectural Press.

Watts, M. J. (2009). Crude politics: Life and death on the Nigerian oil fields: Niger Delta economies of violence (Working Paper 25). UC Berkeley Institute of International Studies.

Weigend, G. G. (1958). Some elements in the study of port geography. Geographical Review, 48(2), 185-200.

Werner, M. (2020). Geographies of production II: Thinking through the state. Progress in Human Geography, 45(1), 178-189.

Wolfrum, S., Stengel, H., Kurbasik, F., Kling, N., Dona, S., Mumm, I., \& Zöhrer, C. (2018). Porous city: From metaphor to urban agenda. Birkhäuser.

Yu, L., Xu, P., Shi, J., Chen, J., \& Zhen, H. (2020). Driving mechanism of port-city spatial relation evolution from an ecological perspective: Case study of Xiamen port of China. Sustainability, 12, 2857.

Zalik, A. (2015). Resource sterilization: Reserve replacement, financial risk, and environmental review in Canada's tar sands. Environment and Planning $A$, 47(12), 2446-2464. 
About the Author

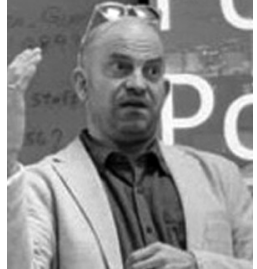

Stephen J. Ramos is an Associate Professor of Urban Planning and Design in the College of Environment + Design at the University of Georgia (USA). He is author of Dubai Amplified: The Engineering of a Port Geography (Ashgate, 2010; Routledge, 2016), co-editor of Infrastructure Sustainability and Design (Routledge, 2012), a founding editor of New Geographies (GSD/Harvard University Press), and an associate editor for Planning Perspectives. He serves on the international advisory board for the Leiden-Delft-Erasmus Universities Port City Futures initiative. 